\title{
Beef Cattle Supply Status with Recent Trends and Future Prospects in Relation to Past in the Cases of Mechara Town, West Hararghe, Oromia Regional State
}

\author{
Tamrat Dinkale \\ Oromia Agricultural Research Institute, Mechara Agricultural Research Center, \\ P.O. Box: 19, Mechara, Ethiopia
}

\begin{abstract}
This activity was conducted 2018 in Daro Labu, Mecahara town, West Hararghe Zone of Oromia National Regional State, Ethiopia. Data were collected from eight (8) butchers, ten (10) brokers and twenty (20) consumers of meat about cattle supply. According to the respondents, all of the cattle are local Hararghe breed. Most of the butchers $(75 \%)$ did not participate in purchasing beef cattle rather than they used brokers for purchasing and only $25 \%$ of butchers purchase beef cattle by themselves. The supply status of beef cattle are depending on the season of the year:- which exceeds beyond requirement during holiday and time for paying cost of inputs like fertilizers and pesticides. $40 \%$ of the brokers responded that total cattle supply status is decreasing from time to time and about $60 \%$ of the respondents (brokers) responded that total cattle supply status is increasing from time to time in mechara town market. About $62.5 \%$ of the butchers have no any information about the relationship between butchery and beef cattle supply and have no worry about problems in counters them in the middle due to the shortage of beef cattle and only $37.5 \%$ of them have the information about the risk of associated beef cattle supply shortage. About $87.5 \%$ of the butchers responded that cattle supply status has been decreasing from year to year while $22.5 \%$ responded that there is no variation. All the butchery has known that animal age and breed type can affect both meat quality and quantity as well as marketability. About $(87.5 \%)$ of butchers responded that they prefer at the age 4 - 6 years first followed by at the age of $2-4$ years, thirdly they prefer at the of $6-8$ years. No one slaughter below the age of 2 years and above of 8 years old. From this results, we observe that animals which are used for all butcheries are at the age of productive age and it needs special attention. All butchery $(100 \%)$ of them have responded no one slaughter female animals (cow or heifer). Most butchers were responded that meat consumption habit increasing being they were joining the business even though the price of the meat dramatically increasing especially from Ethiopian Millennium to date. All the respondents agree that the price of the meat dramatically increasing. The average price when they started is $10 \mathrm{birr} / \mathrm{kg}$ and now a day's $240 \mathrm{birr} / \mathrm{kg}$. Out of 20 consumers, $80 \%$ of them were responded that demand for meat consumption is increasing from time to time even though meat quality is decreasing. All consumers agree that meat flavor is changed and have no sense of flavor due to two reasons: feed and pregnancy.
\end{abstract}

Keywords: cattle supply, Mechara market, butcher, meat consumption, brokers

DOI: $10.7176 / \mathrm{JNSR} / 9-5-01$

Publication date:March $31^{\text {st }} 2019$

\section{INTRODUCTION}

Livestock systems occupy about 30 per cent of the planet's ice-free terrestrial surface area (Steinfeld et al., 2006) and are a significant global asset with a value of at least $\$ 1.4$ trillion. The livestock sector is increasingly organized in long market chains that employ at least 1.3 billion people globally and directly support the livelihoods of 600 million poor smallholder farmers in the developing world (Thornton et al., 2006). Keeping livestock is an important risk reduction strategy for vulnerable communities, and livestock are important providers of nutrients and traction for growing crops in smallholder systems. Currently, livestock is one of the fastest growing agricultural subsectors in developing countries. Its share of agricultural GDP is already 33 per cent and is quickly increasing. This growth is driven by the rapidly increasing demand for livestock products, this demand being driven by population growth, urbanization and increasing incomes in developing countries (Delgado, 2005). The combination of growing demand in the developing world and stagnant demand in industrialized countries represents a major opportunity for livestock keepers in developing countries, where most demand is met by local production, and this is likely to continue well into the foreseeable future (Thornton et al., 2010).

Ethiopia has the largest livestock population in Africa, about 59.5 million head of cattle, 30.7 million sheep, 30.2 million goats, 8.44 million donkeys, 2.03 million horses, 0.4 million mules, 1.16 million camels, 56.53 million poultry and 5.92 million beehives (CSA, 2017) and Daro Lebu district livestock population is about 160,522 head of cattle, 19,653 sheep, 30,0254 goats, 31,354 donkeys, 9 horses, 89 mules, 19,000 camels and 9,9015 poultry (Daro Lebu Agricultural office, 2018 ). The livestock subsector has an enormous contribution to Ethiopia's national economy and livelihoods of many Ethiopian farmers in the various farming system (Belete et al., 2010) and serves as a source of food, traction, manure, raw materials, cash income, foreign exchange earnings and has 
social and cultural values. The sub sector contributes about $45 \%$ of the agricultural GDP and $16 \%$ of the national Gross Domestic Product (GDP) (IGAD, 2010). It also contributes 15\% of the export earnings (Behnke, 2010). In addition to these non-market values, a thriving informal export trade in live animals further emphasizes the significance, albeit unrecognized by official statistics, of livestock (and particularly cattle) in the Ethiopian economy.( Sintayehu GebreMariam. 2013). Population growth, urbanization, economic progress and changing consumer preferences are boosting the demand for livestock products in developing countries (Delgado et al., 2001). Knowledge of reasons for keeping animals is prerequisite for deriving operational breeding goals Based on the result of these study cattle both (oxen and cow) the primary purpose of keeping oxen in Hararghe is for draft power and cash or income generation purpose accounting for $99.4 \%$ of responses. Cows are kept for the purpose of milk and cash generation from sell of cattle $86.6 \%$, while they are also kept for milk purpose only secondly accounting $12.5 \%$ of responses (Rewe et al., 2006).

West Hararghe is well known for its best practices and indigenous knowledge in cattle fattening. Enhancing the production and productivity in the area with available indigenous technical knowledge will help the improvement of the sector in increasing the sector contribution to national and agricultural GDP.( Abdi et al., 2013). Rashid, M., and Shank, R. 1994 also reported that not surprisingly, livestock condition in the mid- and highland areas throughout West and East Hararghe is very satisfactory.

\subsection{Objectives}

$\checkmark$ To assess present-day state of beef cattle supplementation in relation to past trends and whether these trends are likely to continue into the future in Mechara town.

$\checkmark$ To assess reinforcement past increases in meat production are outlined, and the status of meat production systems in Mechara town.

\section{MATHERIALS AND METHODS}

\subsection{Description of the Study Area}

This activity was conducted 2018 in Daro Labu, Mecahara town, West Hararghe Zone of Oromia National Regional State. The capital town of the District, Mechara, which is located at a distance of about 434 and $114 \mathrm{~km}$ from Addis Ababa and Zonal city, Chiro respectively. The total population of the district is 198,918 of which 102,014 and 96,904 is male and female respectively. Out of this population 182,014 and 16,861 is found in rural and Mechara town respectively. (Source: Daro Lebu district Disaster risk and management office action plane, 2018/19). Mechara town is located at $08^{\circ} 36.1772^{\prime}$ N latitude, $040^{\circ} 19.4117^{\prime}$ E longitude and the altitude of 1774 meters above sea level. The rainfall pattern is bimodal, the small rains fall starting from March/April to May and the main rainy season extends from June to September/October with an average annual rainfall of $963 \mathrm{~mm}$ and average annual minimum and maximum temperatures of $14{ }^{\circ} \mathrm{C}$ and $26{ }^{\circ} \mathrm{C}$, respectively. (Dereje et al., 2013).

\subsection{Sampling Techniques}

The study was conducted in Mechara town. About eight (8) butchery house was selected purposively based on the duration they participated in butchery ( $>10$ years), about ten (10) brokers and twenty (20) consumers selected randomly and a total of 38 respondents was participated in this activity. This activity was used structured questionnaires independently for all categories (butcher, broker and consumer). Finally, this structured questionnaires were asked all categories according to their activities that is butchers while they are selling their meat, brokers while they are broking and consumers while they are consuming the meat.

\subsection{Data Collection}

Data collection was made through structured questionnaires that was categorized in to three parts: brokers, butchers and consumers. The interview was made separately for all respondents. Brokers was interviewed during they were broking at market.

\section{RESULTS AND DISCUSSION}

\subsection{Descriptive Analysis}

\subsubsection{Age, Sex and Educational composition of the respondents}

The age of the different classes of respondents are related to experience and the work force that the respondents are participates in different categories of livestock activities practices. The result showed that most of the respondents, butchers, consumers and brokers are found $50 \%, 70 \%$ and $60 \%$ respectively between the age of 36 - 50 (Table 1). From this simple observation result, we can conclude that most of the respondents are found in active age of production and have great role in livestock market activities. About $87.5 \%, 100 \%$ and $100 \%$ of the respondents, butchers, consumers and brokers respectively are males (Table 1). This results showed that only males are participate in meat consumption in butchery and broker activities. On the other hand, the educational level of the respondents were composed of different grades which most of them were categorized under educated. 
According to this results, $62.5 \%$ and $60 \%$ of the butchers and consumers were holding above diploma and $80 \%$ of the brokers are found between $6-12$ grades (Table 1). This simple result indicate that most of the livestock activities (market activities) more shift to educated persons.

\subsubsection{Main occupation and Duration of the respondents in the activity}

The main occupation of the respondents are vary according to the activities they participated. The categories of the respondents were butchers, consumers and brokers which most of them are trader (75\%), NGO and GO workers $(70 \%)$ and farmers $(50 \%)$ respectively (Table 2$)$. From this results it showed that meat is most of consumed by NGO and GO workers. This is might be due to income difference and information of the use of meat use for human being. On the other hand, most of the brokers are farmers which were considering broker as secondary duty and most of the butchers are trader. The duration of the respondents in the activities is almost categorized under the same time serious or length which are $75 \%, 60 \%$ and $50 \%$ of butchers, consumers and brokers respectively of the duration of 10 - 20 years. This indicate that the stability and continuity of the market with profitable. So , the government must due attention for livestock production especially beef and dairy that create sustainable jobs and have a significant roles in poverty reduction. Sintayehu GebreMariam et al., 2010 reported that that livestock continues to be a significant contributor to economic and social development in Ethiopia at the household and national level

Table 1 summary results sex, age and Educational composition of the respondents in the study area

\begin{tabular}{|c|c|c|c|c|c|c|c|c|}
\hline \multirow{2}{*}{\multicolumn{2}{|c|}{ Variables }} & \multicolumn{2}{|c|}{ Butchers } & \multicolumn{2}{|c|}{ Consumers } & \multicolumn{3}{|c|}{ Brokers } \\
\hline & & $\mathbf{N}=\mathbf{8}$ & $\%$ & $\mathbf{N}=\mathbf{2 0}$ & $\%$ & $\mathbf{N}=\mathbf{1 0}$ & $\%$ & Total $\mathbf{N}=\mathbf{3 8}$ \\
\hline \multirow[t]{2}{*}{ Sex } & Male & 7 & 87.5 & 20 & 100 & 10 & 100 & \\
\hline & Female & 1 & 12.5 & 0 & - & 0 & - & \\
\hline \multirow[t]{5}{*}{ Education } & Illiterate & 1 & 12.5 & 0 & - & 0 & $\mathbf{0}$ & \\
\hline & $1-5$ grade & 0 & - & 2 & 10 & 1 & 10 & \\
\hline & $6-10$ grade & 1 & 12.5 & 4 & 20 & 4 & 40 & \\
\hline & $11-12$ & 1 & 12.5 & 2 & 10 & 4 & 40 & \\
\hline & Diploma and above & 5 & 62.5 & 12 & 60 & 1 & 10 & \\
\hline \multirow[t]{3}{*}{ Age } & $20-35$ years & 2 & 25 & 4 & 15 & 1 & 10 & \\
\hline & $36-50$ years & 4 & 50 & 14 & 70 & 6 & 60 & \\
\hline & $>50$ & 2 & 25 & 4 & 15 & 3 & 30 & \\
\hline \multirow[t]{4}{*}{ Marital status } & Married & 7 & 87.5 & 12 & 60 & 6 & 60 & \\
\hline & Unmarried & 0 & - & 6 & 30 & 1 & 10 & \\
\hline & Divorced & 1 & 12.5 & 2 & 10 & 2 & 20 & \\
\hline & Widowed & 0 & - & 0 & - & 1 & 10 & \\
\hline
\end{tabular}

Table 2 summary results of Occupation and Duration of the respondents in the activity in the study area

\begin{tabular}{|c|c|c|c|c|c|c|c|c|c|}
\hline \multicolumn{3}{|l|}{ Variables } & \multicolumn{2}{|c|}{ Butchers } & \multicolumn{2}{|c|}{ Consumers } & \multicolumn{3}{|c|}{ Brokers } \\
\hline & & & $\begin{array}{l}\mathbf{N}= \\
8\end{array}$ & $\%$ & $\mathbf{N}=\mathbf{2 0}$ & $\%$ & $\begin{array}{l}N= \\
10\end{array}$ & $\%$ & $\begin{array}{l}\text { Total N } \\
=38\end{array}$ \\
\hline \multirow[t]{4}{*}{ Main Occupation } & Farmers & & 0 & - & 0 & - & 5 & 50 & \\
\hline & Trader & & 6 & 75 & 4 & 20 & 2 & 20 & \\
\hline & $\begin{array}{l}\text { NOG and } \\
\text { workers }\end{array}$ & $\mathrm{GO}$ & 0 & - & 14 & 70 & 1 & 10 & \\
\hline & $\begin{array}{l}\text { Farmers } \\
\text { Traders }\end{array}$ & and & 2 & 25 & 2 & 10 & 2 & 20 & \\
\hline \multirow{2}{*}{$\begin{array}{l}\text { Duration of the respondents in } \\
\text { activities }\end{array}$} & $<10$ years & & 1 & 12.5 & 4 & 20 & 4 & 40 & \\
\hline & 10 - 20 years & & 6 & 75 & 12 & 60 & 5 & 50 & \\
\hline
\end{tabular}

\subsection{Beef cattle supply status at Mechara town Market}

Mechara town is one of the town that found in West Hararghe, the capital city of Daro Lebu district. Mechara livestock market is held on Saturday as a main market that composed of different classes of livestock marketing activities. This market is including different classes and age of cattle and small ruminants (sheep and goats) which are most dominated by bulls and goats respectively. Beef cattle market supply on Mechara town marketing system have long term history which was started legal taxation in 1963. (Source:- Local elder Ato Tefera G/ Hiwot). Starting from that time, Mechara town butchers buy their beef cattle from this market which almost the cattle is local (Hararghe breed). According to (Sintayehu Gebre Mariam et at., 2013). Meat is derived almost exclusively from indigenous local cattle breeds. Most of the butchers (75\%) did not participate purchasing beef cattle rather than they used brokers for purchasing and only $25 \%$ of butchers purchase beef cattle by themselves for butcher. 
According to most respondents (brokers), the supply status of beef cattle are depending on the season of the year:which exceeds beyond requirement during holiday and time for paying cost of inputs like fertilizers and pesticides. About $40 \%$ of the brokers which participate in the questionnaires responded that total cattle supply status is decreasing from time to time in mechara town market even though the price of cattle dramatically increasing. But about $60 \%$ of the respondents (brokers) which also participate in the questionnaires responded that total cattle supply status is increasing from time to time in mechara town market. Little, P. D. et al., 2010 analyzing FAO livestock production data, they find that from 1978 to 1998 the volume of beef production increased by 3\% per year on average in East Africa, which is attributable to increased herd sizes. In contrast to this, $100 \%$ of butchers responded that total cattle supply status is decreasing from time to time in mechara town market due to feed shortage and drought. Fekede et al., (2016) reported that the trend of livestock production reduced from time to time due to various factors like Shortage of grazing land \& animal feed, drought, shortage of Veterinary service, lack of improved animal breeds for all livestock type, grazing land conflict among tribes, low price of livestock and their product and high meddling of broker in livestock marketing Daro Lebu and Mieso District.

Figure 1Mechara cattle market and marketing system

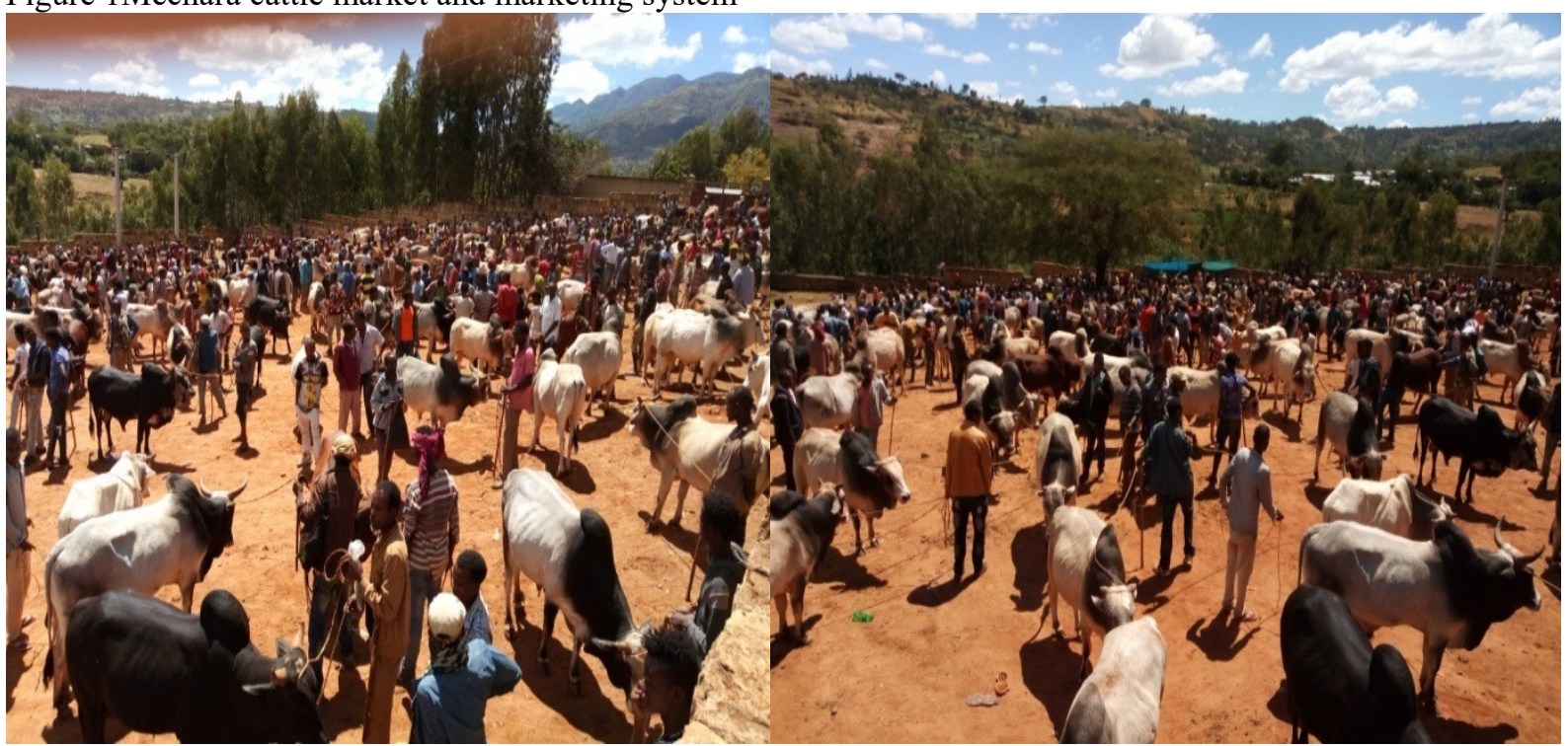

\subsection{Assumption of Different Actors on Livestock Supply of Mechara Market}

\subsubsection{Butchers}

In Mechara town, butchery was started followed the begging of the Mechara town. In this activity, eight (8) butchery house where participated. It is the most income generation and main occupation of most of butchers. According to the respondents, $62.5 \%$ have no any information about the relationship between butchery and beef cattle supply on the market and have no worry about problems in counters them in the middle due to shortage of beef cattle. They were started butchery simply due to beer pressure as they thought that it is a profitable jobs. About $37.5 \%$ of the butchers have the information about risk of associated beef cattle supply shortage on market due to different reasons like feed shortage, illegal market, drought and production fail.

Butchers have opposite idea with the brokers about the status of cattle supply on Mechara town local market. About $87.5 \%$ of the respondents (butchers) responded that cattle supply status has been decreasing both body presentation appearance and quantity being they were participate in this activities. They put the reasons that most fattened animals (bulls and oxen) are transported to other place like Addis Abeba and Adama. They also said that drought severity and animal feed shortage is the other problem shortage of animals on market. Little, P. D. et al., (2010) found out that there is an obvious trend in parts of southern Ethiopia and elsewhere in the country of a shift from keeping cattle to camel and goat species. The primary driving forces are the severity of drought and its frequency and a change in vegetation toward browse species. According to this respondents, all of them are obtained their beef cattle from local market, Mechara town and they are not consider breed types. They depend only on profitability of the cattle according to their criteria's. 
Figure 2 Selected Mechara Butchery house during surveying

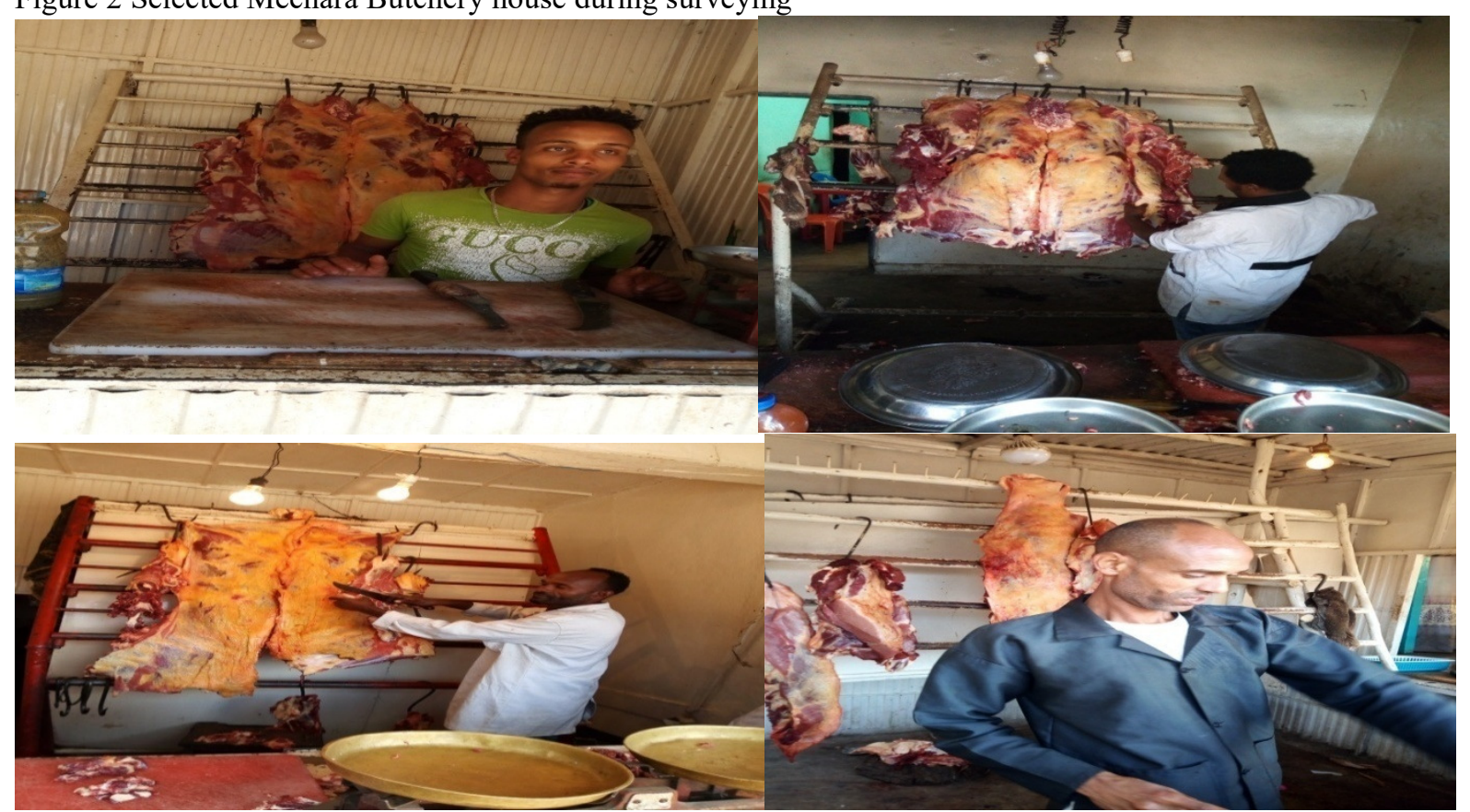

Animal age and breed type is one of the most factors that affect meat quality. Almost all of the respondents know that this factors are depressing both meat quality and quantity as well as marketability. The interview was including the questionnaires about at what age and which types (male or female, bull or oxen, heifers or calves) they slaughtering to identifies the role of butcheries on production of livestock. Almost all of the respondents $(87.5 \%)$ responded that they prefer at the age $4-6$ years at the first followed by at the age of $2-4$ years. At the third place they prefer at the of $6-8$ years. On the hand, they responded that no one slaughter below age of 2 years and up of 8 years old. This is due to age affecting meat quality especially over 8 years very tuff and not tenderable. From this results, we observe that animals which are used for almost all butcheries are at the productive age and it needs especial attention.

In terms of types (male or female, bull or oxen, heifers or calves) most of the time slaughtered was included in questionnaires. According to the respondents all (100\%) of them were responded no butchery house slaughter female animals (cow or heifer). They put the reason why they are not slaughter is the woreda livestock office told them not to slaughter this class of animals being they are productive. They also said that the government drive the policy on this classes of animals not to be slaughtered. But the reality is far from what the butchers responded. During conducting this activity, the butchers prepare female (heifers) for slaughtering as seen at the following pictures.

Figure 3 Female animals which are ready for slaughter

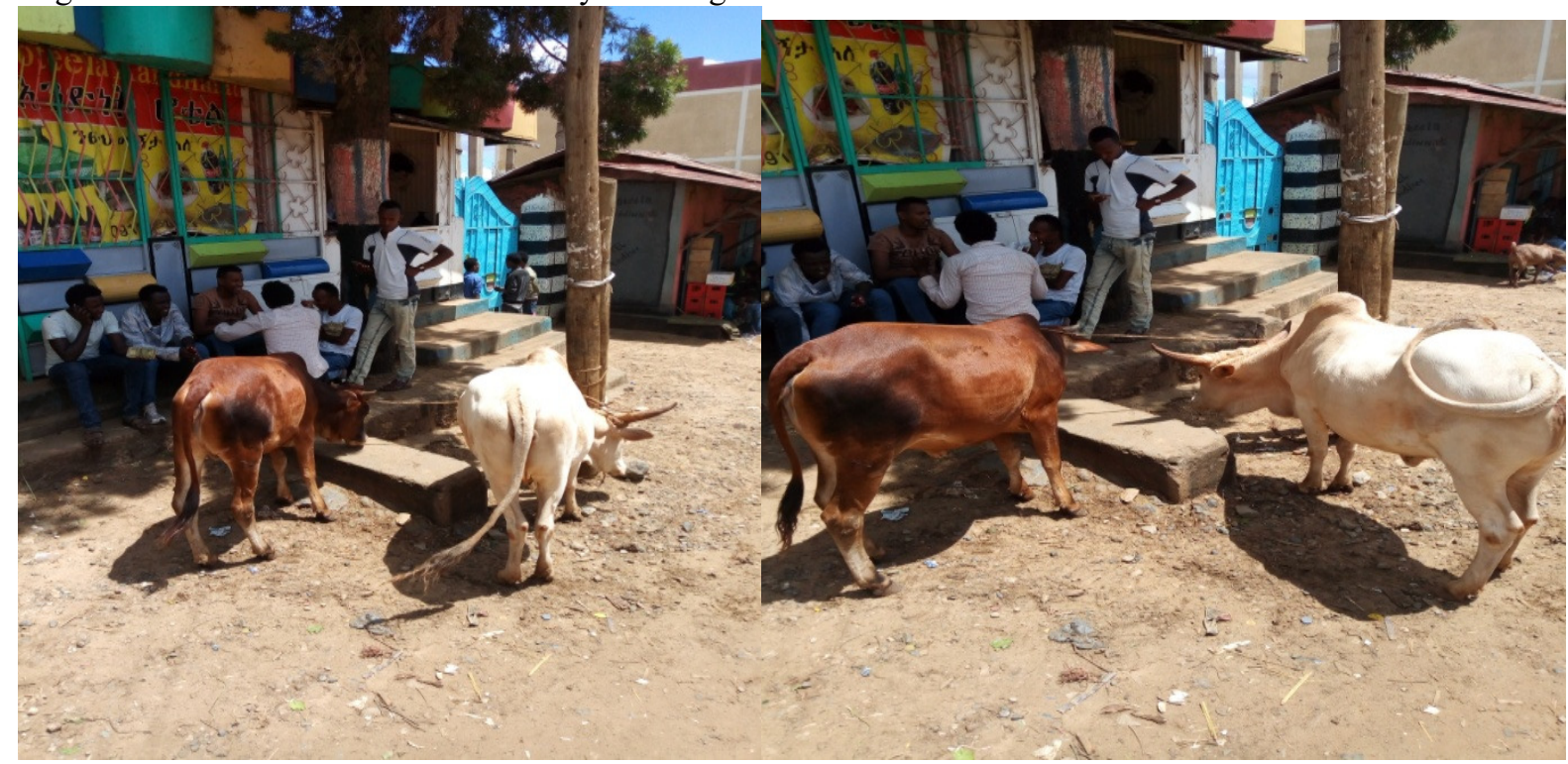


In this simple over view survey, about $75 \%$ of the butchers were responded that meat consumption habit increasing being they were joining the business and only 25\% responded that unchanged. Tambi and Maina (2003). describe three key ways increased demand can be met with increased supply: increased herd sizes, increased off take rates from a given herd size, or increased productivity per animal. All the respondents agree that the price of the meat dramatically increases especially from Ethiopian Millennium to date. The average price when they started is $10 \mathrm{birr} / \mathrm{kg}$ of meat and now a day's $240 \mathrm{birr} / \mathrm{kg}$ is the common price for all butchers. They reason out that meat price increment is due to animal price increases from year to year. The other reasons are taxes, services like brokers, abattoirs payment, house rent and cost of feed till slaughter. As accustomed throughout the country different price based meat cutting is not practiced by all butchers in Mechara town.

All butchers responded that, they are grading animals according to their fat contents which are low fatter, average fatter and high fatter. This grading system were the same from the time they were butchering. All participants agree that the price of beef cattle are dramatically increasing due to cost of feed, drought and cattle supply status decreases. The average price that the respondents respond for low fatter, average fatter and high fatter at the time they started butcheries was 1500,2200 and 3000 birr per cattle respectively and now a day's on average, this price shift to 12,000, 20,000 and 35,000 birr per cattle respectively. They also estimate the price of this grade level of animals after ten years forward will be on average raise to 20,000,30,000 and 55,000 birr per cattle respectively. They put the reason of price increments is human population and feed cost increasing.

All respondents (butchers) agree that the government must take intervention to increase livestock production and productivity through ensuring year round feed supply, through new technology introduction to the area and set policy against illegal cattle export to abroad. In addition to this genetic improvement of local cattle must due attention. Other ways they said that meat after ten year might be only present through mirror as a photo for wealthy person.

\subsubsection{Brokers /Middlemen}

An important feature of the livestock marketing system in most of the livestock markets in Ethiopia is the involvement of brokers/middlemen in many segments of the marketing chain They match buyers and sellers and facilitate transaction, and in some cases they indeed provide for a valuable service. Throughout the field work for this study, many teams identified several situations in which the channel from producer to final market would include one to three brokers/middlemen.

Brokers are major actors in many livestock market in Ethiopian. They act as intermediary price negotiators between sellers and buyers. They offer services of holdings grounds for animals of small farmers that are not sold on the market day. ( Hurrissa, 2009)

Mechara livestock marketing system also involving different actors that facilitate buying and selling of different classes of livestock. Since this market have long year history, brokers have the main actors in livestock market and marketing system. According to the participants (brokers), about $80 \%$ are broking any age of animals and only $20 \%$ of them are broking beef cattle. The brokers also responded that about market composition in terms of age and sex categories. They said that livestock market in Mechara town is changed to younger animals, especially to heifers due to old bulls and oxen are fattened and sold to other market like Adama and Addis Abeba to reasonable price. Sintayehu et al. (2013) reported similar result that a local butcher cannot absorb the large volumes available from feedlots are (averaging around 500 heads/cycle) thereby forcing large-volume export sales. (Aklilu 2002) reported that a 1999/2001 data indicates that Bale has been the major supplier of fattened steers to these terminal markets (about 38\%) followed by Hararghe (29\%), Borana (8.4\%), Arsi (6.2\%) and Wolayta (3.8\%). Most brokers, about $60 \%$ agree that cattle supply at mechara market increases from time to time being established even though age and sex composition changed. They put the most reason for increment that the human population increases that supply cattle to markets. The rest, about $40 \%$ of them are disagree the increments of cattle on the market but agree the composition changes. All brokers (100\%) responded that they did not broking selecting breed types for all purposes (butchery and other services). They broking any types of breed in relation to the benefit they get.

All brokers responded that, they are grading animals according to their fat contents which are low fatter, average fatter and high fatter. This grading system were the same from the time they were broking. All respondents agree that the price of any classes of animals are dramatically increasing due cost of feed and feeding. The average price that the respondents respond for low fatter, average fatter and high fatter at the time they started broking was 1200, 1800 and 2500 birr respectively and now a day's on average, this price shift to 10,000, 18,000 and 30,000 birr respectively which is almost similar with butchers. The brokers also estimate the price of this grade level of animals after ten years forward will be on average raise to 15,000, 25,000 and 45,000birr respectively. They put the reason of price increments is human population and feed cost increasing. In relation to this, the price of animal products (meat, milk, eggs etc) are dramatically increasing. The average price of meat when they starting to broking was $12 \mathrm{birr} / \mathrm{kg}$ and now $240 \mathrm{birr} / \mathrm{kg}$ which have dramatically increasing. 
Figure 4 Brokers while broking cattle at Mechara Market and interviewed

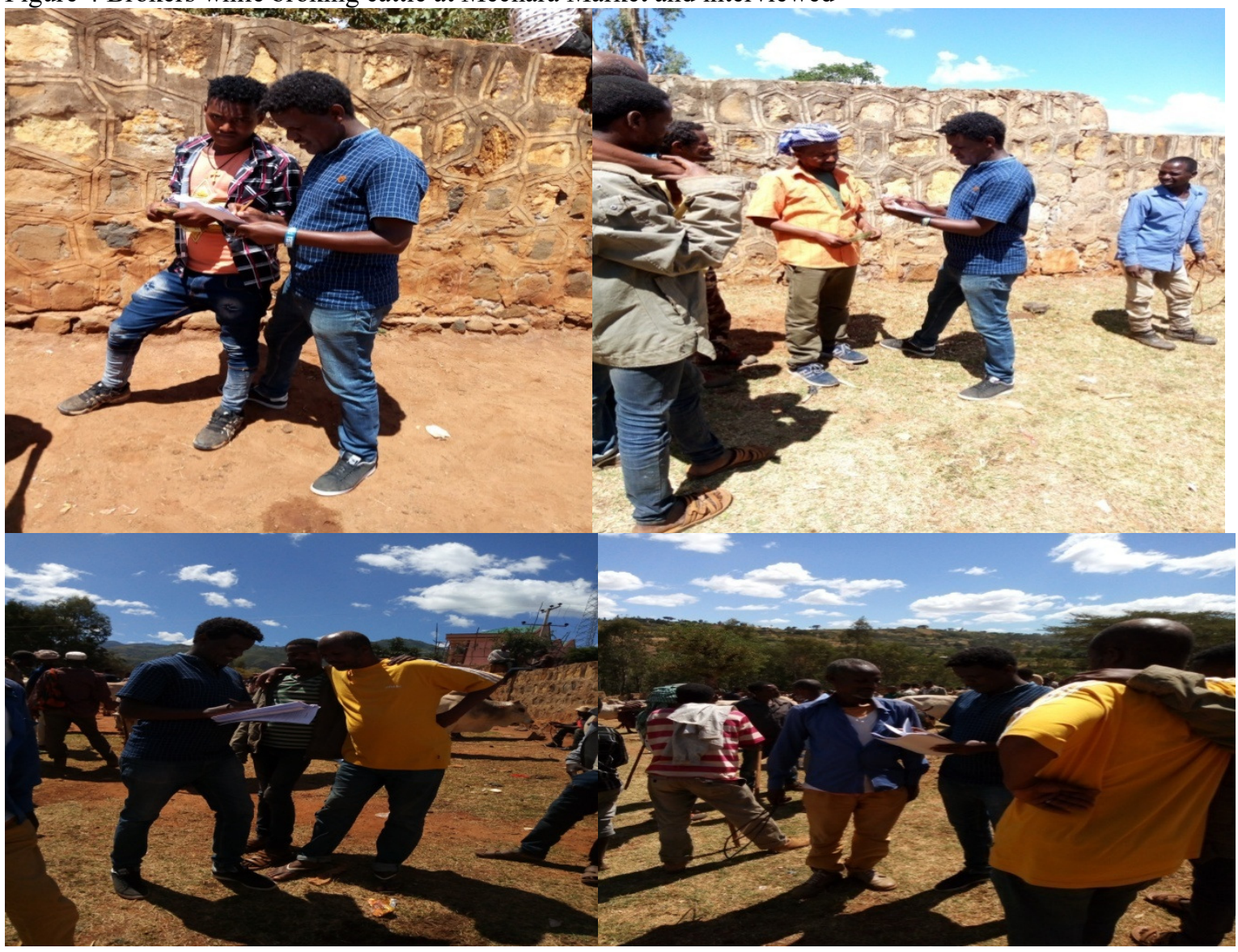

\subsubsection{Meat Consumers}

Competition between domestic consumers and livestock supply is un balanced rate of increments. it also true that meat quality and quantity depend on accessibility of livestock on market and meat consumption demands. Out of 20 participants (consumers), $80 \%$ of them were responded that demand for meat consumption is increasing from time to time even though they agree that meat quality is decreasing.

According to (AASTU. 2016; AACCSA. 2015) report, there are several reasons for this low meat consumption, including low per capita income, high domestic meat prices and the fasting days by the Orthodox Christian which lasts for at least 200 days in a year that reduces the aggregate demand by $20-35 \%$ ( Aleme et al; UNDP. 2015). However, the domestic meat demand is believed to increase with increasing literacy and family income. Shapiro et al., (2015). On the other hand, $20 \%$ of the respondents (consumers) disagree meat consumption habit decreases from year to year due to quality of the meat decreases. All respondents reason out that especially meat flavor is changed and have no any sense of flavor due to two reasons: feed and pregnancy. They respond that animal feed is affecting meat quality that feeding system of the animals shift from organic (free grassing and hay feeding) to industrial by product like nuck cake, wheat bran and etc. The second reason is the pregnancy. About $90 \%$ of the consumers responded that most of the butchers slaughtering pregnant heifers and productive cows that have a pregnancy and meat obtained from such animals have a bad flavors. To protect and enhance meat quality, the respondents (consumers) suggest that the concerning body (government) must establish committees at market level which make sure that the cattle is not pregnant. Little, P. D. et al., (2010) reported that Consumers often tend to evaluate meat quality based on tenderness, juiciness and flavor of cooked meat. On the other hand, almost all of them (100\%) agree that the price of meat increases dramatically over the last ten years. It is the other factor that causes decreasing of meat consumption. According to (Little, P. D. et al., (2010), increasing the flow of animals into meat exports or live animal exports will lead to price increases in the domestic meat market if supply is not expanding as rapidly as combined domestic and export demand

Under this finding, the questionnaires was includes the status of butchery in mechara town to find out the relationship between beef cattle supply and butchery house numbers as well as meat selling practice. About 50\% of the respondents respond that butchery house was increasing over the last ten years while $20 \%$ responded that the number of butchery was decreasing and $30 \%$ responded that there is no change. In terms of different meat cut price, all the consumers did not buy different cut in different price. 


\section{CONCLUSION AND RECCOMENDATION}

Ethiopia has the largest livestock population in Africa general and Hararghe is one of the famous potential livestock production area. The livestock subsector has an enormous contribution to Ethiopia's national economy and livelihoods of many Ethiopian farmers and serves as a source of food, traction, manure, raw materials, cash income, foreign exchange earnings and has social and cultural values. West Hararghe is well known for its best practices and indigenous knowledge in cattle fattening. Almost all of cattle marketing activities in Mechara town is dominated by male (husband) and market and marketing activity start to shifting from illiteracy to educated person. Livestock market and marketing is stability and continuous with market profitable in Mechara town. Cattle market and supply also stability and continuity. Brokers is the most actors in buying and selling cattle in Mechara town market. Supply status of beef cattle are depending on the season of the year:- which exceeds beyond requirement during holiday and time for paying cost of inputs like fertilizers and pesticides. Cost of beef cattle are dramatically increasing over ten years due to cost of feed and drought.

Butchery is the most income generation and main occupation of most of butchers. Butchers and brokers have opposite idea about cattle supply status that brokers says increases from time to time but butchers says decreases which put reasons most fattened animals (bulls and oxen) are transported to Addis Abeba and Adama, drought severity and animal feed shortage. Meat is derived almost exclusively from indigenous local cattle breeds. Animal age and breed type is one of the most factors that affect meat quality. Meat consumption is almost of consumed by NGO and GO workers at Mechara town and the consumption is increasing from time to time. But meat quality is decreasing due to two reasons: feed and pregnancy. The animals which are used for slaughter for any butcheries are at the productive age. About $90 \%$ of the consumers responded that most of the butchers slaughtering pregnant heifers and productive cows that have a pregnancy and meat obtained from such animals have a bad flavors. The concerning body (government) must establish committees at market level which make sure that the cattle is not pregnant before slaughtered. And also government must due attention for livestock production especially beef and dairy that create sustainable jobs and have a significant roles in poverty reduction

\section{REFERENCES}

AACCSA (Addis Ababa Chamber of commerce and Sectoral Associations). 2015. Value chain Study on Meat Processing Industry in Ethiopia.

Abdi Etafa, Kemal Kasim, Yassin Esmael and Muleta Debela. 2013. Cattle production in west hararghe: an opportunity and constraints assessments in Darolabu, Oda bultum, Gemechis and Chiro districts, Oromia Regional State, Ethiopia. International Journal of Livestock Production Research Vol, 1, 01-15.

Addis Ababa, Science and Technology University (AASTU). 2016. Ethiopian Agro-industry Strategy Meat Industry Sub-sector Strategic Plan 2016.

Aklilu, Y. in collaboration with Patrick Irungu and Alemayehu Reda. 2002. An Audit of Livestock Marketing Status in Kenya, Ethiopia and Sudan. Volume 1. Community-Based Animal Health and Participatory Epidemiology Unit . Nairobi, Kenya.

Aleme Asresie, Lemma Zemedu and Adigrat, E. 2015. Contribution of Livestock Sector in Ethiopian Economy: A. Advances in life Science and technology, 29, 79-90

Behnke R. 2010. The Contribution of Livestock to the Economies of IGAD Member States: Study Findings, Application of the Methodology in Ethiopia and Recommendations for Further Work. UK: Odessa Centre, IGAD Livestock Policy Initiative, Great Wolford; 2010. IGAD LPI Working Paper 02-10.

Belete Shenkute, 2010. Production and marketing systems of small ruminants in Goma district of Jimma zone, western Ethiopia.

CSA, 2017. Agricultural Sample Survey 2016/17 (2009 E.C.).Volume II. Report on Livestock and Livestock Characteristics (Private Peasant Holdings). CSA, Addis Ababa, Ethiopia. 2:585.

Daro Lebu district Disaster risk and management office, 2018. Action plane of Daro Lebu district Disaster risk and management office, Annual report 2018/19).

Delgado, C. 2005 Rising demand for meat and milk in developing countries: implications for grasslands-based livestock production. In Grassland: a global resource (ed. D. A. McGilloway), pp. 29-39. The Netherlands: Wageningen Academic Publishers.

Delgado, C., Rosegrant, M., Steinfeld, H., Ehui, S. and Courbois, C. 2001. Livestock to 2020: The next food revolution. Outlook on Agriculture, 30(1), 27-29.

Fekede Gemechu, Kinde Lemessa, Tadesse Melka, Birmaduma Gadisa, Shimalis Dekeba, and Asfaw Zewdu. 2016. Effect of Climate Change on Agricultural Production and Community Response in Daro Lebu and Mieso District, West Hararghe Zone, Oromia Region National State, Ethiopia.

Hurrisa B. 2009. Community driven Livestock Marketing Models: in the case of Borena livestock trade share company of Ethiopia. Paper present at regional symposium on livestock marketing in north Africa; working towards 'best practices', 21-23 October, 2009. TAES/SPS-LMM.10 pp.

Little, P. D., Behnke, R., McPeak, J. and Getachew Gebru. 2010. Future scenarios for pastoral development in 
Ethiopia, 2010-2025. Report, 2, 387-410.

Rashid, M., and Shank, R. 1994. United nations development programme. Emergencies Unit for Ethiopia. Technical report: Rough guide to animal diseases in Ethiopia.

Rewe T O, Indetie D, Ojango J M K and Kahi A K 2006: breeding objectives for the Boran breed in Kenya: Model development and application to pasture-based production systems. Animal Science Journal 77:63-177.

Shapiro BI, Gebru G, Desta S, et al. 2015. Ethiopia Livestock Master Plan. ILRI Project Report. Nairobi, Kenya

Sintayehu et al, 2013. Study of the Ethiopian live cattle and beef value chain, ILRI Discussion Paper No. 23

Sintayehu GebreMariam, Samuel Amare, Baker, D. and Ayele Solomon. 2010. Diagnostic study of live cattle and beef production and marketing: Constraints and opportunities for enhancing the system

Sintayehu GebreMariam, Samuel Amare., Baker, D., Solomon, A. and Davies, R. 2013. Study of the Ethiopian live cattle and beef value chain. ILRI Discussion Paper 23. Nairobi: International Livestock Research Institute

Steinfeld, H., Gerber, P., Wassenaar, T., Castel, V., Rosales, M. \& de Haan, C. 2006. Livestock's long shadow: environmental issues and options. Rome, Italy: FAO.

Tambi, N. and Maina, O. 2003. Patterns of Change in Beef Production and Consumption in Africa. Scientific and Technical Review, OIE, 22(3): 965-76

Thornton, P. K. 2010. Livestock production: recent trends, future prospects. Philosophical Transactions of the Royal Society B: Biological Sciences, 365(1554), 2853-2867.

Thornton, P. K. et al. 2006. Mapping climate vulnerability and poverty in Africa. Nairobi, Kenya: ILRI. See http://www. dfid.gov.uk/research/mapping-climate.pdf. 